\title{
Voluntary Peer Observation
}

\section{Steven T. Urick}

\section{Shizuoka University}

\section{Reference Data}

Urick, S. T. (2021). Voluntary peer observation. In P. Clements, R. Derrah, \& P. Ferguson (Eds.), Communities of teachers \& learners. JALT. https://doi.org/10.37546/JALTPCP2020-08

Voluntary peer observation (VPO) is a promising tool for the professional development of language teachers. It has been documented that peer observation can provide benefits for observers and observed teachers. VPO has the potential to eliminate some of the negative feelings that can be associated with evaluative and other types of observation by giving control of the entire process to the observed teacher. A five-step scheme is introduced and the author provides a brief account of a VPO conducted with a colleague.

自発的ピア・オブサベーション (VPO) は、語学教師の専門能力開発のための有望なツールである。ピア・オブサベーション は、観察者と被観察者である教員の双方に利益をもたらすことが実証されている。PPOは、被観察者である教員にプロセス全 体の統制をゆだねることで、評価を目標とした観察等に伴う否定的な感情を払拭できる可能性がある。本論では5段階のスキ 一ムが導入され、著者が同僚と実施したVPOの簡祭な説明を提供する。

lassroom observation is often used for teacher evaluation and maintaining best practices within a language learning program. A problem with such observations is that they can be one-sided and are often stressful for practitioners. An alternative is peer observation (PO). PO has been found to help teachers learn from each other, share knowledge about specific groups of students and curricula, and foster reflective practice (Day, 2013; Guo, 2005; Motallebzadeh, Hossiennia \& Domsky, 2017).

While functioning as one type of PO, voluntary peer observation (VPO) moves one step further than other types of PO. For VPO, the person being observed volunteers and is in control of the process. With the observed teacher in charge, the process can be designed to reduce the potential negative effects, and it can be tailored to address what a practitioner wants to investigate-issues in a particular classroom or the practitioner's teaching methods.

There were three goals for this project. First, I have undertaken this project with the hope that it can serve as a simple introduction to VPO, and that more language teachers will consider using this method of professional development. Second, I wanted to get input from a colleague on student performance in a course I was teaching where fostering student investment had often been a challenge. Through his observation and our discussion of it, I hoped to hear an objective report of the ways in which students were participating in the classroom and find some ways to make improvements. Finally, I wanted to experience VPO firsthand and see what benefits or shortcomings could be observed.

\section{Peer Observation as a Tool for Professional Development}

There is support for the idea that observers can benefit from peer observation. Asaoka (2019) suggests that less experienced practitioners can observe experienced teachers and develop expertise by emulating them. While benefits for teacher trainees are often espoused, there is no reason why experienced language teachers cannot also benefit from being an observer. Wajnryb (1992, p. 7) points out that observing releases the observer from the need to perform, allowing the freedom to "observe, absorb, and reflect." LarsenFreeman (2000) introduces a group of idealized class observations and invites the reader to use the information as "a foil" to tease out ideas about approaches to teaching as they relate to personal experience, information from research literature, and even social values (p. 4). The emphasis is on reflective practice and the observation functioning as impetus for the observer's critical thought. Relating theoretical constructs to classroom practice is one potential area for development, as is considering the larger social context of the learning environment. 
Clearly, however, there can be benefits for observed teachers as well. A study of English language teachers in Cuba found that "[peer] feedback helps teacher educators to critically examine their own teaching and compare their beliefs about teaching and learning to their actual classroom practices." (Smith, 2016, p. 107) In the context of English language teacher training in Iran, Moradkhani (2018) reports that informal collaboration after peer observation that was initiated by the observer or observed teachers "enhanced the participating teachers' understanding of teaching techniques or procedures." (p. 66)

In comparison to being observed by someone in a higher position in the hierarchy of an institution, peer observation has more potential to provide the observed teacher with a comfortable environment to receive and process feedback. Asaoka (2019) reports that peer observation in her context led to feedback that was done in a "non-threatening manner" (p. 116). Bardsdale (2018, p. 10) points out that peer feedback can be "less stressful" than other types of feedback. It is important to understand that this is more than simply an issue of the feelings of the observed teacher. If we accept the notion that we must aim for teacher autonomy, and if we see teachers as "the primary initiators of their own development," (Wajnryb, 1992, p. 10) then the nature of the power relations between observer and observed teacher must be taken into account. A practitioner will be more likely to critically engage with feedback and potentially incorporate it into their teaching practices if they feel empowered to make their own decisions about how to act on it. Feedback from a peer is more likely to foster engagement and lead to observed teachers actively and creatively developing teaching strategies.

\section{Voluntary Peer Observation as an Alternative Method}

Although peer observation can contribute to professional development in the ways documented above, there is still the potential for problems. For example, Ahmed et al. (2018) describes the response of English language teachers to peer observation in a Saudi Arabian context. Six of the 12 observed teachers reported being nervous during the observation. In this study 10 of the 12 observed teachers were not allowed to choose their observer, and it is quite possible that this contributed to the negative feelings (Ahmed et al., 2018). In the context of a diploma program for secondary school English language teachers in Hong Kong, Dos Santos (2016) found that peer observation had a "negative reputation" among teachers (p. 44). In the program he describes, this appears to arise from a lack of understanding of the purposes and methods used for peer observation, as well as misperception that the observations were to be evaluative.
This paper suggests a carefully planned voluntary peer observation to avoid such problems. The benefits in favor of VPO are as follows: the observed teacher is not being evaluated by the observer-she or he is in control of the observation, the ensuing conversation about the results, and the application of the data analysis to the learning environment. Furthermore, the observed teacher can choose someone they are comfortable with to do the observation. They can give instruction on how they would like the observation notes to be taken, and in what format they would like the feedback to be given. The observed teacher can decide what sort of conversation they would like to have with the observer after the observation to review the data.

With the observed teacher functioning as the decision maker, not only is it easier to maintain a positive atmosphere, but this also leads naturally to appropriate observation methods and goals. It is the engaged classroom practitioner, after all, who knows best what issues or problems exist in the learning environment. The practitioner knows the students, the materials used, and the specific ways in which course objectives are to be met. The practitioner is also best positioned to identify issues related to her or his teaching methodology to focus on.

\section{VPO Procedure}

The scheme I developed has five steps and an optional sixth one. First, the person to be observed needs to find a colleague who is willing to do the observation. Second, the practitioner identifies classroom issues that she or he wants to investigate. Third, the person to be observed decides the method for observation and communicates this to the observer. The next step is the actual observation. Finally, after the observation, feedback is given and a discussion is conducted between the observer and the observed teacher. Optionally, as the sixth step, the observed teacher can produce a written report. This can be reflections, written for the practitioner only, a report to be shared with colleagues, or part of a larger research project.

Classroom issues for observation can be divided into two groups, the first being related to students. In designing the observation, the practitioner can ask questions such as the following: What types of problems have occurred in the classroom to be observed? How are students participating in the class? Are they on task? Cooperative? What difficulties do the students seem to be having? What do they appear to be excelling at?

The focus can alternatively be placed on the teacher. How does the teacher deal with off-task students? How are activities designed in relation to lesson goals and course objectives? What kind of encouragement or explanation does the teacher provide? 
What aspects of the practitioner's approach to teaching is she or he trying to develop or reconsider?

After determining which issues the observation will focus on, the practitioner needs to make decisions about how the observation is to be done. There are many different options for the observation method, and many resources are available that can be referred to for ideas. For example, McDonough and McDonough (2004) provide a variety of approaches to observation that can be used as is or adapted to meet the needs of a practitioner. Wajnryb $(1992$, p. 7$)$ offers that "the language a teacher uses when giving instructions," or "the patterns of interaction that emerge in a lesson" can be the focus of an observation. A traditional observation tool that employs coding can be used, such as COLT (Spada and Frohlich, 1995). The observer can be asked to produce field notes, which give a running account of the action in the classroom. Another alternative is focused note-taking, where the observer pays attention to a particular aspect of the class, taking notes on that aspect. With practical considerations and the goals for observation taken into account, the observation period can be any length, from one session to multiple sessions.

Next, the practitioner should provide the observer with information about the course, students, context, type of observation, and observation method. Compiling detailed information into one document and providing it to the observer can be extremely helpful. It is very important that the observation method is explained clearly. Ideally, a meeting can be held so that anything that needs clarifying can be discussed.

During the observation, it is important for the observer to remain as unobtrusive as possible. Yet however much effort is applied to avoid affecting the classroom dynamics, the observer will almost always have an influence on the behavior of students, just by virtue of her or his presence. This should be considered when the results of the observation are interpreted (Wajnryb, 1992).

After the observation is performed, the observer and observed teacher should meet to discuss the data from the observation. In many cases it will be helpful for the observer to provide the observed teacher with a copy of the records from the observation before the meeting so as to give the observed teacher time to examine the data. If necessary, the observer can produce a differently organized or more legible version of notes taken. It is recommended that the observed teacher take control of the dialog, discussing the data and its implication with the observer.

\section{A Sample VPO Observation}

The class for the observation I and my colleague undertook had 38 students of widely varying proficiency levels. The course was at a private university in Japan, and the students were all English majors. The guidelines for the course described a challenging course where cultural awareness was fostered, and discussions were undertaken on differences between cultures. An academic speaking and listening textbook were used, which included extensive vocabulary work, content on aspects of American culture, and mini-lectures. While some of the students were thriving in the class, many students seemed to be struggling to understand the content. Walking around the room after giving students an activity to do, I would often find that a number of students had finished the activity, while others had not even begun. Students often looked sleepy, and sometimes a few students would put their heads on the desks, apparently unable to stay awake. When I gently spoke to these students, they would attempt to participate in the activities, but they and others seemed to be struggling with more than just sleepiness. Some students did not bring a positive attitude to the classroom. For example, one student told me that she didn't like English, and just hearing it made her tired.

With the observation, I wanted to explore the students' level of engagement in activities. The observer and I met and discussed the scheme and the approach I was asking him to use. I explained that I wanted him simply to take notes on what he saw students doing and that after that I wanted to have a conversation with him to discuss the class. Before the observation I provided the observer with a document outlining the course, the issue to be focused on, and the observation method. The observer watched the first 60 minutes of the 90 -minute class and took field notes. He did not provide me with a copy of the field notes before our meeting, but rather brought the field notes to the meeting.

During our meeting, which was recorded, the observer first read the field notes to me, which provided many examples of less-than-ideal participation by students. For example, before class began, few students were using their textbooks to review. Later, during an information exchange activity, some pairs of students were not using verbal exchange to get the needed information but were simply copying from each other's books. At one point in the class, I asked students to work together to do a vocabulary matching exercise, but most students were not communicating with a partner. When the lecture video was played and students were given a note-taking activity, the observer noted that only about 6 of the 38 students had their pens moving.

During the discussion that followed, we identified some options for dealing with students in the class who were not on task. First, we agreed that the difficulty level was 
probably one reason students were not fully participating. To deal with this, using more repetition and review of vocabulary seemed to be a strategy that could help. The observer also recommended using images in vocabulary learning activities, which he felt could help some of the less proficient students. Confronted with a difficult text, some of these students may have been just tuning out and giving up. Using images to teach vocabulary may give such students a better chance to engage in the classroom work. A final option we discussed was designing a future syllabus for the course that covered less material. This idea overlaps with the idea of doing more vocabulary review-having less course content would help provide the time necessary for additional vocabulary review.

\section{Discussion}

As mentioned above, $\mathrm{PO}$ is recognized as an effective tool for professional development. Observing teachers can develop expertise through emulation (Asaoka, 2019). Observing can also foster reflection on the part of the observer (Wajnryb, 1992). Observation can help the observed teacher look critically at teaching methods (Ahmed et al., 2018) and it can lead to a better grasp of teaching techniques (Moradkhani, 2018). Further, PO can be less stressful for observed teachers than other types of observation (Asaoka, 2019; Bardsdale, 2018).

Yet, although $\mathrm{PO}$ has benefits, there is also one important negative aspect, which can be eliminated by the use of VPO. Although PO can be more comfortable than other types of observation, there are still examples of $\mathrm{PO}$ that are stressful or threatening for the observed teacher (Ahmed et al. 2018; Bardsdale, 2018). This demands attention, especially if an institution's professional development approach values reflective practice and teacher empowerment. VPO can eliminate much of the stress involved by placing the teacher at the center of the process, in control of designing, implementing and interpreting the results of an observation.

Above I have outlined an example of VPO that demonstrated the benefits of the observed teacher being in control. However, this example is not meant to be prescriptive, as there are a wide variety of ways in which VPO can be conducted. Whatever objectives are decided upon, and whatever method is chosen, this type of observation is likely to be more successful when the observed teacher is a reflective, critically engaged practitioner In order to design the observation, it is crucial for the observed teacher to be able to identify issues to investigate. Also, in order to benefit from analysis and discussion of the data produced, the observed teacher must be open to changing some of the ways she or he has been planning or teaching a course.
One method that may make VPO more effective is pairing other methods of gathering data with it. In the observation outlined above, the data obtained confirmed that not all students were participating fully. The reasons for this were hypothesized but were not supported by evidence from students. The observer and I felt that the most significant problem was with the level of vocabulary, but we could not say this with a high level of certainty. Perhaps some students were prevented from fully participating because of affective factors, such as a lack of confidence or a negative attitude towards English. Or perhaps some students were hindered by a lack of proper sleep or other factors. In such a case as this, data from students, such as surveys or interviews could help confirm our hypothesis or perhaps shed light on other reasons for students' difficulties.

As mentioned above, VPO has solid potential for use as a tool for professional development. Working with a peer can help eliminate the pressure and anxiety that can accompany observations by supervisors or senior colleagues. Furthermore, when the observed teacher is in charge, there are two additional benefits. First, VPO can be an opportunity for critical reflection on one's teaching. Second, goals and methods fully appropriate for a given classroom and instructor can be chosen for this kind of observation. While it may be most effective when paired with other methods of data collection, VPO should be regarded as a powerful tool for the language teacher.

\section{Conclusion}

This paper has discussed VPO as a necessary non-threatening aspect of professional teacher development. It has presented a prototype of VPO and its techniques for implementation. The voluntary peer observation technique introduced has been found to be useful and has made sense from a classroom perspective.

\section{Bio Data}

Steven T. Urick is an Associate Professor at Shizuoka University in Shizuoka, Japan. His research interests include student perspectives on learning, methodology, and curriculum design.

\section{References}

Ahmed, E., Zaimuariffudin, S. N., Shah, S. R., \& Channa, M. A. (2018) Peer observation: A professional learning tool for English language teachers in an EFL institute. World Journal of Education, 8, 73-86. https://doi.org/10.5430/wje.v8n2p73 


\section{JALT2020}

COMMUNITIES OF
TEACHERS \& IEARNERS

Asaoka, C. (2019). Early professional development in EFL teaching: Perspectives and experiences from Japan. Multilingual Matters.

Bardsdale, J. (2018). ELT observation \& feedback handbook. Bardsdale.

Day, R. R. (2013). Peer observation and reflection in the ELT practicum. Journal of Language and Literature Education, 8, 1-8.

Dos Santos, L. M. (2016). Foreign language teachers' professional development through peer observation programme. English Language Teaching, 9(10), 39-46. https://doi.org/10.5539/elt. v9n10p39

Guo, Y. (2005). An investigation of ESL teachers' experience of peer consultation. Canadian Journal of University Continuing Education, 31(2), 17-36.

Larsen-Freeman, D. (2000) Techniques and principles in language teaching. Oxford University Press. McDonough, J., \& McDonough, S. (1997). Research methods for language teachers. Arnold.

Moradkhani, S. (2018). EFL teachers' perceptions of two reflection approaches. ELT Journal, 72(1), 61-71. https://doi.org/10.1093/ccy030

Motallebzadeh, K., Mansooreh, H., \& Domsky, J. G. H. (2017). Peer observation: A key factor to improve Iranian EFL teachers' professional development. Cogent Education, 4, 1-12. https://doi. org/10.1080/2331186X.2016.1277456

Smith, S. J. (2016). Cuban voices: A case study of English language teacher education. The International Education Journal, 15(4), 100-11. Retrieved from https://files.eric.ed.gov/fulltext/ EJ1130392.pdf

Spada, N., \& Frohlick M. (1995). COLT Communicative Orientation of Language Teaching

Observation Scheme: Coding conventions and applications. National Centre for English Language Teaching and Research.

Wajnryb, R. (1992). Classroom observation tasks: A resource book for language teacher and trainers. Bell and Bain. 